\title{
Structure of the nucleoli in Angiosperms
}

\author{
M. PODBIELKOWSKA \\ Botanical Institute, University of Warsaw \\ (Received: August 30, 1970)
}

\begin{abstract}
:
The nucleolus structure in the cells of numerous Angiospermae plants was studied with light microscope. The living material was examined under phase and anoptral contrast. Microscopical observations were also carried out on the material fixed in chrome-formalin or in uranyl-formalin.

An occurrence of two structural components of nucleolus was demonstrated: an amorphous ground substance and nucleolonema. Cytochemical analysis have shown that considerable amounts of RNA and acid proteins were located in the amorphous substance while nucleolonema was composed of basic proteins and slight quantities of RNA.
\end{abstract}

\section{INTRODUCTION}

The problem of the internal structure of the nucleolus has become of no small importance since it has been recognized that it takes part in the production of cytoplasmic and nuclear proteins by synthesizing ribosomic RNA and ribosomic proteins (Biernstiel 1967).

The first to describe the internal structure of the nucleolus were E st a ble and Sotelo $(1951,1955)$. They established that the nucleolus has a complex structure, visible in the light microscope after special fixation. This structure consists of two elements: a filamentous nucleolonema and an amorphous substrate, described by the authors as ,pars amorpha”, in which the former is immersed.

This concept of the nucleolonematic structure of the nucleolus has not been generally accepted, although it was confirmed by numerous authors (Hertl 1957, Rodkiewicz 1959, Zenkteller 1959, Setterfield 1961). Some investigators believe that this theory is based on an erroneous interpretation of the vacuolar structure (S e r r a 1958, A l b aneze, Bologuari et al. 1963). Others, as for instance Sitte (1965) suppose that the nucleolonema is not a structural element of the nucleolus proper but an intranucleolar chromatin. 
The results of investigations and observations in the light microscope are up to date controversial. They are particularly difficult to interpret, since the fixation and staining methods routinely applied in cytology do not reveal in the nucleolus any structural differentiation.

The complex structure of the nucleolus was demonstrated in the eleciron microscope. Investigations on the submicroscopic structure of the nucleolus, e.g., Bernhard et al. 1955, Lafonta ine 1958, Sitte 1959, Davis 1960, Bourne and Danielli 1960, Yasuzumi and $\mathrm{S}$ a vad a 1958 , S t e ven s 1965 , C hou in ard 1965 , allowed to distinguish in the nucleolus, beside amorphous protein, two structural RNA containing the following components: fibrils about $50-80 \AA$ thick and ribosome-like particles, about $150 \AA$ in diameter (Estable et al. 1966, Birnsitiel 1967). These structural components are not randomly mixed. In most nucleoli there are zones which are predominantly fibrillar or predominantly granular. The fibrillar zones are sourrounded by particulate materials. The fibrillar material may be arranged rather loosely in thread-like filamentous elements or in a compact mass. The granular component is sometimes organized in thread-like elements about $0,1 \mu$ in diameter. These elements often appear irregular and anastomosing. Most authors believe that the granular zone corresponds to the nucleolonema. But the nucleolonema as described by Estable and Sotelo (1955), S o t e 1.0 (1966) and La C o ur (1966) is centrally located and sourrounded by the "pars amorpha".

In view of those discrepancies a reinvestigation of the nucleolus structure in the light microscope may be of interest.

The starting point for the present investigations were the unexpected results of the experiments performed in the Department of plant Anatomy and Cytology of the Warsaw University, which proved that a reduction of the acetic acid content in Navashin's fixative makes it possible to reveal the nucleolonematic structure of the nucleolus.

The investigations here presented included: observations on living cells, analysis of the influence of various fixatives on the nucleolar structure in cells with different physiological activity, comparative studies on the structure of the nucleoli in species with different structure of the cell nucleus, observations on the transformation of the nucleolus during mitosis and cytochemical analysis of the staining properties of the nucleolus.

\section{MATERIAL AND METHODS}

Observations on living cells were made on the epidermis or hairs of some dozen species, mounted in 8 percent sucrose solution in tap water, with the aid of phase and anoptral contrast microscopes. Most suitable for these observations are: the epidermis of Allium cepa scales, the sta- 
minal hairs of Tradescantia virginiana and the hairs of Cucurbita pepo leaves.

Studies on fixed material were carried out on the apical root meristems of Allium cepa, Cucurbita pepo, Avena sativa, Vicia faba, Phaseolus vulgaris, Zea mays, Secale cereale, Lycopersicon esculentum and on the embryo sac of Aconitum napellus and Delphinium sp.

The composition of the fixatives used and the concentration of their components, expressed in percents, are as follows:

1. mixtures of chromic acid, acetic acid and formalin, i.e., chrom-acetic-formalin: $\mathrm{CrAF} 0,5-4-20$, CrAF $0,5-1-20$, CrAF $0,5-$ $0,5-20$;

2. formalin $10 \%, 20 \%$ and $40 \%$ with $1 \% \mathrm{CaCl}_{2}$, neutralized with calcium carbonate $24 \mathrm{hrs}$ before fixation;

3. mixtures of chromic acid and formalin, i.e., chrom-formalin: $\mathrm{CrF}$ $0,5-10, \mathrm{CrF} 0,5-20, \mathrm{CrF} 0,5-40, \mathrm{CrF} 0,2-10, \mathrm{CrF} 0,2-20, \mathrm{CrF}$ $0,2-40$;

4. mixture of potassium dichromate and formalin, i.e., dichrom-formalin, $0,5-20$, UF $1-20$, UF $1-10$;

5. mixture of acetic acid and formalin, i.e., acetic-formalin: AF 0,5$-20$

6. mixtures of uranyl nitrate and formalin, i.e., uranyl-formalin: UF $0,05-10$, UF $0,12-10$, UF $0,25-10$, UF $0,5-10$, UF $0,12-20$, UF $0,5-20$, UF $1-20$, UF $1-10$;

7. mixtures of lanthanum chloride and formalin, i.e., lanthan-formalin: LaF $0,1-10$, LaF $0,2-10$, LaF $0,5-10$, LaF $0,2-20$, LaF 0,5 - 20, $\mathrm{LaF} 1-10$.

Fixation time was $24 \mathrm{hrs}$. After fixation, the material was washed in tap water for $12 \mathrm{hrs}$, dehydrated in a graded series of ethanol, passed through xylene and embedded in paraffin. Section thickness was $2-5 \mu$.

In additional experiments the effect of Estable and Sotelo's (1955) fixative was tested on Allium cepa and Cucurbita pepo root apexes.

The influence of the various fixatives on the nucleolus structure was examined on sections stained with iron haematoxylin after Heidenhain or with gentian violet after Newton.

Moreover various special staining methods were applied: 0.25 percent toluidine blue in McIlvaine's citric-phosphate buffer, $\mathrm{pH} 3.4$ and $7.4,37^{\circ} \mathrm{C}$, $1 \mathrm{hr}$.; 0,25 percent cresyl violet in citric-phosphaite buffer, $\mathrm{pH} 3.4$ and $7.4,37^{\circ} \mathrm{C}, 1 \mathrm{hr}$.; Feulgen reaction; methyl green-pyronin; phosphine F S in citric-phosphate buffer, $\mathrm{pH}$ 2.4; fast green $\mathrm{F} \mathrm{C} \mathrm{F,} 0.1$ percent solution in citric-phosphate buffer, $\mathrm{pH} 4.0,7.4,8.0$ and 8.9 ; orange $\mathrm{G}$ and aniline blue, $\mathrm{pH} 3.0$ and 2.4; acid haematein test.

Nucleic acids were removed by treatment of sections in 5 percent trichloroacetic acid solution at $90^{\circ}$ for $15 \mathrm{~min}$., or in $5 \mathrm{~N} \mathrm{HCl}$ at $60^{\circ} \mathrm{C}$ for one hour. Trypsin in phosphate buffer, $\mathrm{pH} 8.0$ at $37^{\circ} \mathrm{C}$ was applied for 
one hour to remove proteins. Lipids were removed in bromine water for 18 hrs.

Photomicrographs were taken with a Zetopan (Reichert) microscope Agfa $\mathrm{FF}$ and Orwo $10^{\circ}$ Din films.

\section{RESULTS}

\section{Observations on living cells}

It was expected that observation on living cells will be of essential importance for the interpretation of the results obtained on fixed material. It appeared, however, that the epidermis and hair cells on which the investigations were performed, have very minute nucleoli. For instance the diameter of the nucleoli in the onion epidermis cells is $0.8-2 \mu$ and in the meristematic cells of the staminal hairs of Tradescantia it is $0.5-0.8 \mu$. In view of such small dimensions of the nucleoli it is difficult to examine their structure more precisely. In spite of this, it was possible to establish on living intact cells, showing intensive cytoplasmic movement, that the nucleoli are not homogeneous. Besides the vacuoles occurring here and there, darker, poorly outlined strands are visible in the nucleoli under positive contrast (table I, 1-3). In dying or dead cells, on the other hand, the nucleoli are completely homogeneous.

\section{Influence of the fixative composition on the nucleolus structure}

Preliminary investigations indicate that the chrom-acetic-formalin fixative (CrAF 0,5-4-20) reveals the internal structure of the nucleoli if acetic acid is omitted in the mixture.

In the first group of experiments, modifications of this fixative were used with varying acetic acid content without change in the chromic acid and formalin amounts. Those modifications are: CrAF 0.5-4-20, CrAF 0.5-1-20, CrAF 0.5-0.5-20 and CrAF 0.5-0-20.

In roots fixed in chrom-acetic formalin with a high acetic acid content, the nuclesli are homogeneous in all cells. Close examination of onion roots apical meristems fixed in fixative modifications with lowered acetic acid content (CrAF 0.5-1-20 and CrAF 0.5-0.5-20) revealed in the same section different patterns of the internal structure of the nucleolus, forming a continuous series of transitions from the loose nucleolonema skeins embedded in homogeneous matrix in the inner zone of the root, to almost homogeneous dense conglutinate in the outer zone. The area of the nucleolonematic zone is dependent on the acetic acid content in the fixative. It is the largest after CrAF 0.5-0-20.

This fact is decisive for the interpretation of the structures observed. 
The graded series of patterns of conglutinated nucleolonematic structures, formed in the same section under the influence of the fixative, indicate that not the nucleolonematic, but the homogeneous structure of nucleoli should be considered as an artefact.

The experiment showing the homogenizing effect of acetic acid on the structure of the nucleolus demonstrated the dependence of this effect on the composition of the fixing mixture, which actually kills the cell. The composition of this killing mixture is different at various depths in the tissue, fixed by a coumpound fixative, owing to the differential penetration rates of its components. It appears, too, that the structures already fixed are resistant to the deforming influence of the slower-penetrating component of the fixative.

In the following experiments the apical meristems of Allium cepa roots were fixed in some dozen kinds of fixative mixtures, containing various combinations of the components of Navashin's fixative as well as lanthanum and uranyl salts, used in electron microscopy for contrasting structures containing nucleic acids.

The experiments proved that formalin is the main fixing agent revealing the internal structure of the nucleolus. Addition of a small amount of chromic acid or uranyl salts has a favourable effect. Most suitable for revealing the nucleolar structure was found to be fixation in chrom-formalin ( $\mathrm{CrF} 0.2-10$ or $\mathrm{CrF}$ 0.5-20) as well as uranyl-formalin (UF 1-10), and staining with iron haematoxylin or crystal violet.

It was found by using these methods for root apical meristems of various plants that the inner structure of the nucleolus consists of two structural components: the nucleolonema in a characteristic tangled configuration similar to that of the prophase nucleus, showing a high affinity to stains, and on amorphous ground substance with lower staining affinity, in which the nucleolonema is embedded (Table 1, 4, 5, 6).

\section{Influence of cell activity on the structure of the nucleolus}

In order to elucidate this problem, the structure of nucleoli was examined in three type of cells in the root apex of Allium cepa, viz. in specialized, metabolically little active cells of the columella, and in two different types of metabolically active cells: those of the cortex in the cell division zone and those differentiating into the members of the central metaxylem vessel.

The striking differences concerned, in the first place, the size of the nucleoli. As might be expected, the largest were characteristic for the tissues with highest metabolism. The diameter of these nucleoli varied from 5 to $15 \mu$. The smallest were found in highly specialized cells with low metabolic activity (ca $1 \mu$ ). 


\title{
LEGENDS OF TABLES
}

\author{
Table I
}

Phot. 1. Nucleus with two nucleoli in the live epidermal cell from Allium cepa scale, under phase contrast.

Phot. 2. The same nucleus with two nucleoli under anoptral contrast. Distinct nonhomogeneity of nucleolus structure.

Phot. 3. Nucleus with three unhomogeneous nucleoli in the hair cell from Tradescnatia virginiana anther, under anoptral contrast.

Phot. 4, 5. Nucleoli in the cells from the division zone of Cucurbita pepo root apex; chromo-formalin $0.5-20$, Heidenhain haematoxylin.

Phot. 6. Nucleolus in the cell from the division zone of Allium cepa root apex; chromo-formalin $0.5-20$, Heidenhain haematoxylin.

\section{Table II}

Phot. 1, 2. Nucleoli in the cells of the future metaxylem in Cucurbita pepo root apical meristem; chromo-formalin $0.5-20$, gentian violet.

Phot. 3. Nucleolus in the cell of the future metaxylem from Allium cepa root apical meristem; uranyl-formalin $1-10$, Heidenhain haematoxylin.

Phot. 4. Nucleolus in the antipodes of Aconitum napellus embryo sac; chromoformalin $0.5-20$, Heidenhain haematoxylin.

Phot. 5. Structure of the ovary cell nucleolus from the Aconitum napellus embryo sac; chromo-formalin $0.5-20$, Heidenhain haematoxylin.

Phot. 6, 7. Nucleolus in the secondary nucleus of Aconitum napellus embryo sac; chromo-formalin $0.5-20$, Heidenhain haematoxylin.

\section{T a ble III}

Intensity of the nucleolus structures staining with the use of acid and basic dyes

I. After fixation with uranyl-formalin $1-10$.

II. After fixation with $10 \%$ formalin $+\mathrm{CaCl}_{2}$.
A) Heidenhain haematoxylin
a) direct staining
b) after hydrolysis with TCA
B) cresyl violet, $\mathrm{pH} 3.4$
C) cresyl violet, $\mathrm{pH} 7.4$
D) fast green, $\mathrm{pH} 3.4$
E) fast green, $\mathrm{pH} 7.4$ 
Table I
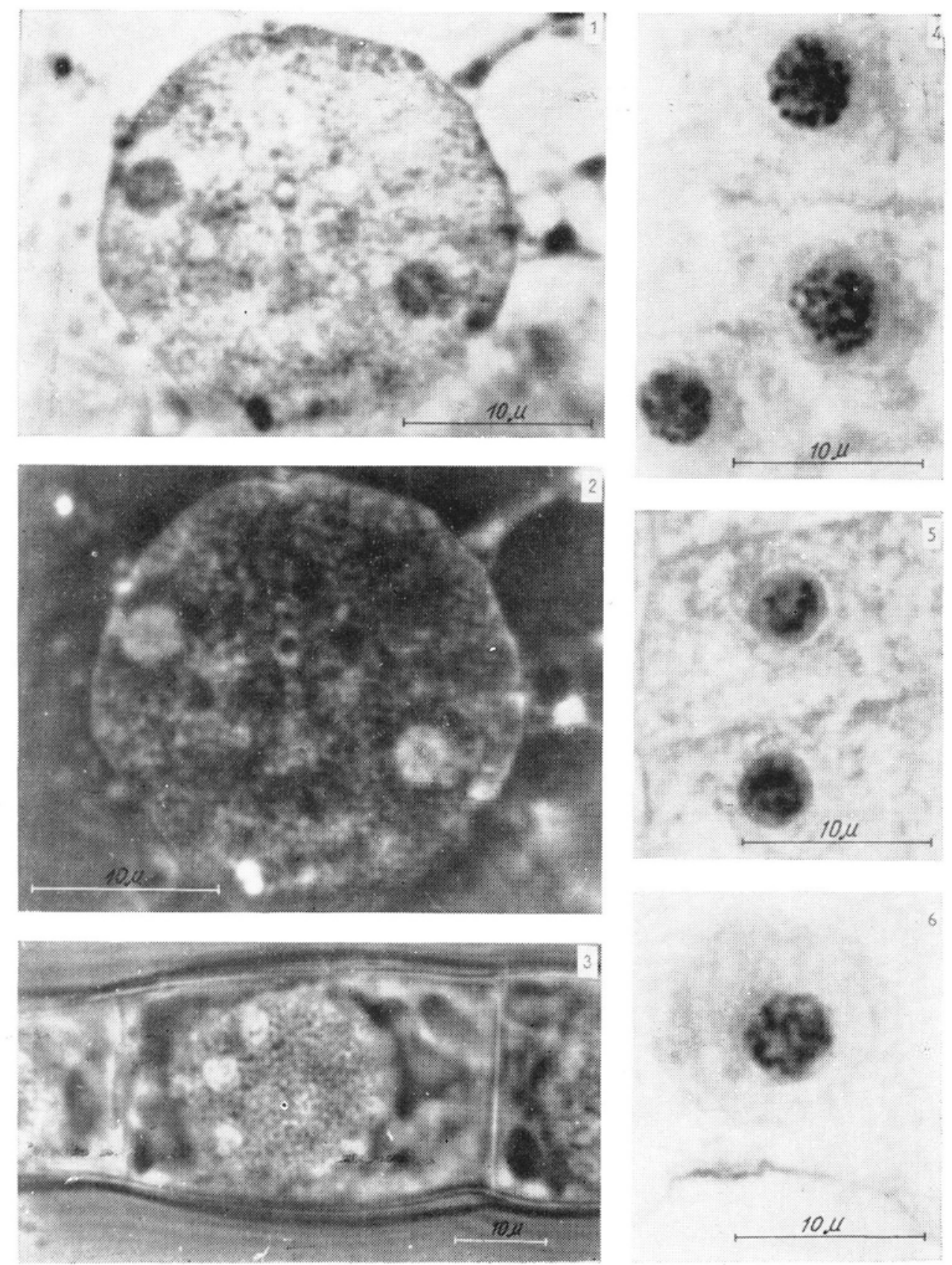
Table II
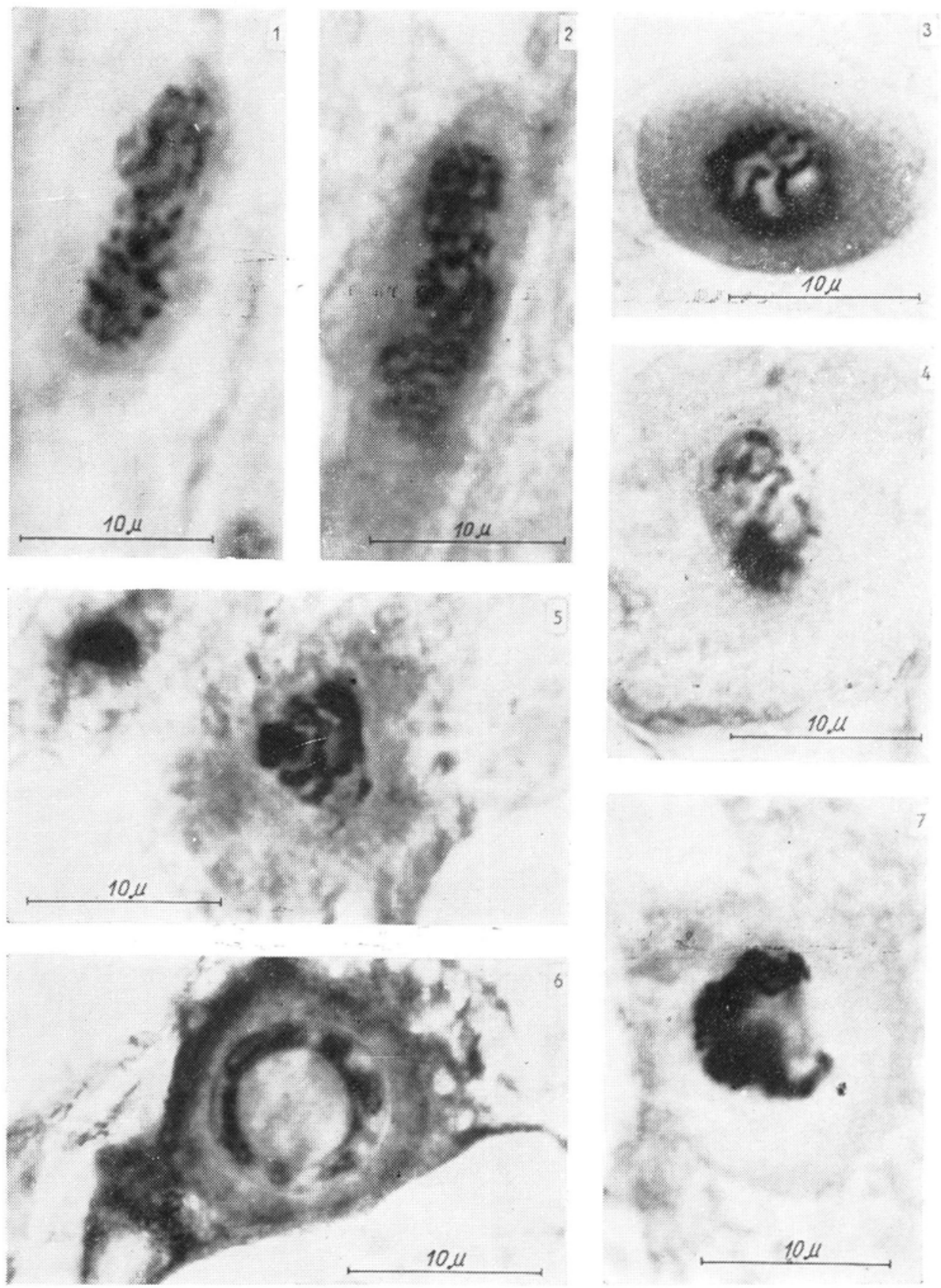
$\mathrm{Table}$ III

1

A
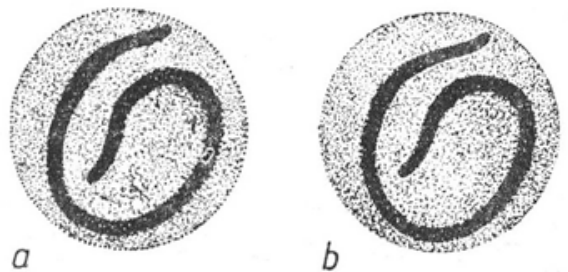

B

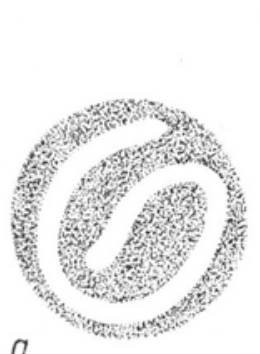

a

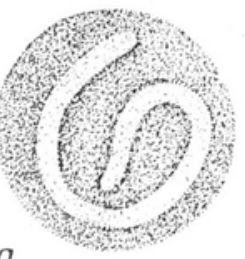

a

$D$

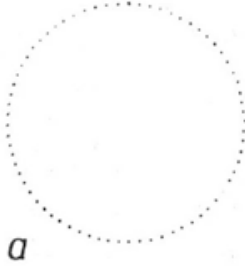

E b

$D$

b
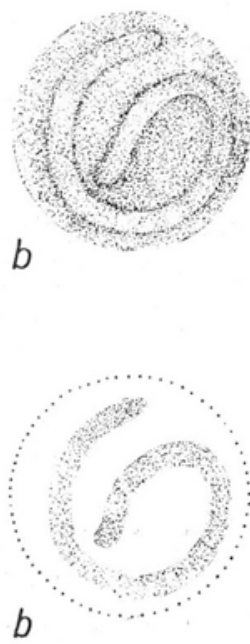

II

A

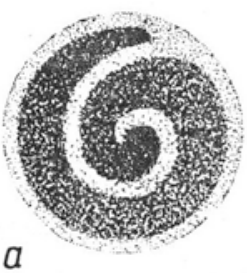

b

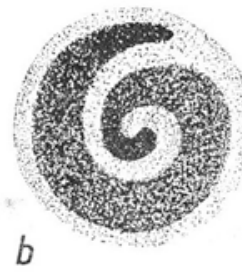

B
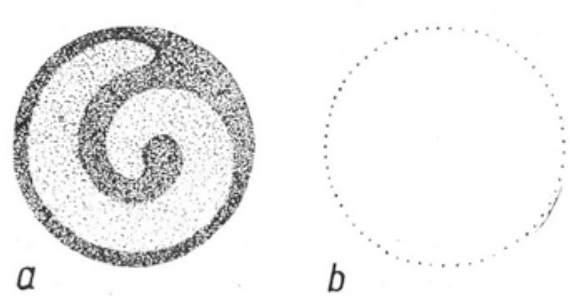

c
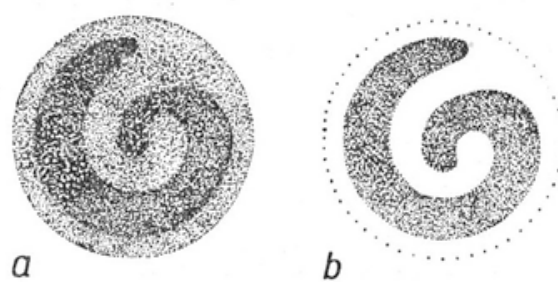

$D$
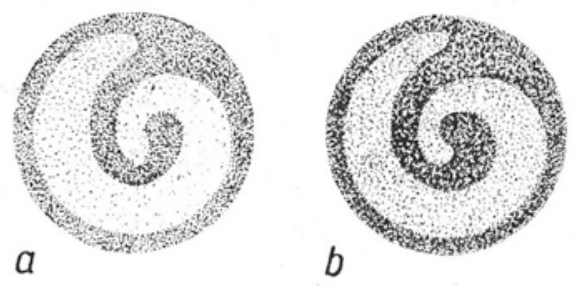

E

$\alpha$

b 
The fact that the size of the nucleoli is dependent on the physiological state of the cells has long been known. B u v a t (1944) took advantage of it to determine the metabolic activity of the meristem cells in the shoot apex. It appears now that beside the size differences there are, too, striking differences in the internal structure of the nucleoli.

In the little active differentiated cells of the root caps the nucleoli are not only very small, but have a compact structure. Their ground substance is very scarce. The nucleolonema is contracted on a small area forming a dense skein, and has a strong tendency to coalesce under the influence of fixatives. Such nucleoli stain heavily as a whole and their structure is difficult to examine.

In the meristematic tissue, the structure of much larger nucleoli is easier to recognize. They abound in ground substance and their nucleolonemata are loosely coiled in skeins resembling in appearance the prophase nucleus (Table I, 4-6).

In the differentiating metaxylem cells various arrangements of the nucleolonema may be seen in greatly elongated nucleoli. As compared with the meristematic cells, the coils are here still looser (Table II, 1-3).

The dependence of the elaborate nucleolar structure upon the active state of the cells is clearly shown in the embryo sacs of the ranunculacean genera Aconitum and Delphinium.

In the egg-cell and antipodal cells of those plants the nucleolar structure is loose, composed of very thin, seemingly interconnected threads, forming sometimes distinct loops (Table II, 4, 5). The nucleoli in the secondary embryo sac nucleus have a specific structure. The nucleolonema is here loosely coiled in the peripheral zone of the nucleolus and the central zone is occupied by a large vacuole (Table II, 6, 7).

Comparison of the internal structure of nucleoli in cells with a different degree of metabolic activity thus indicates that, in highly active cells with large nucleoli the nucleolonema has the form of a loose skein embedded in a large amount of substrate, whereas in little active cells the interior of small nucleoli is almost filled with a compact mass of nucleolonema, and the substrate is hardly visible.

It would seem, therefore, that the nucleoli of cells with low activity are formed almost exclusively of nucleolonema. With more intensive activity of the nucleoli, not only the quantity of nucleolonema substance but also that of the substrate increases, this leading to a looser structure of the nucleolus.

\section{The nucleoli of reticulate and euchromocentric nuclei}

The structure of nucleoli in nuclei of the reticulate type, e.g. Allium, Avena, Secale and Vicia is the same as in the euchromocentric type, e.g. Cucurbita, Phaseolus and Lycopersicon. It is evident, therefore, that the 
type of nuclear structure does not affect the in'ternal structure of the nucleolus (Table I, 4-6).

In nuclei of reticulate type, all the chromosomes, for spatial reasons, have but little possibility of changing their position in the course of telophase transformations. The limitation of movements of SAT-chromosomes with which the nucleoli are connected makes the fusion of the primary nucleoli formed in telophase difficult or impossible. Consequently, in reticulate nuclei of meristematic cells, the same number of nucleoli is generally observed as was primarily formed in telophase.

In the investigated plants with nuclei of euchromocentric type (Phaseolus, Cucurbita, Lycopersicon) the number of nucleoli in the interphase is usually smaller than that occurring in telophase. Mostly, there is one large nucleolus. The reduced number of nucleoli, and the consistent increase of their size are due to the fusion of primary nucleoli during telophase and posttelophase transformations. This is made easy by the telophasic displacements of chromosomes in the euchromocentric nuclei.

\section{Changes in nucleolar structure during mitosis}

In further studies it was attempted to establish the changes occurring in the two structural components of the nucleolus visible in the light microscope, the substrate and the nucleolonema, during mitosis. The investigations were made on the root meristems of Allium cepa fixed in chrom-formalin ( $\mathrm{CrF}$ 0,5-20), and in uranyl-formalin (UF 1-10) and stained by iron haematoxylin or crystal violet.

In the initial stage of prophase, the nucleolus undergoes no noticeable changes. Its shape, size and internal structure remain the same as in late interphase. In middle prophase, a reduction of the nucleolar volume is observed owing to a gradual disappearance of the substrate and drawing together of the nucleonema. Further diminution in volume of nucleolus in late prophase results from continued disappearance of the amorphous substrate and the contraction of the nucleolonema. During disappearance of the nuclear membrane, the nucleolus is suddenly dissolved.

In the course of telophase the nucleoli may be first distinguished in the form of minute granules associated with satellite chromosomes. Initially these nucleoli look like a compact coalesced lump of nucleolonema. As telophase progresses the volume of the nucleolus considerably increases. This allows to distinguish in it the strongly-staining nucleolonema from the weaker-stained substrate. The nucleolonema, at first short and compact, becomes longer and looser until a typical interphase nucleolus is reconstructed. It seems, therefore, that the telophase transformations are nearly the same as those ocurring in prophase, but in reversed order.

To complete the picture of the nucleolonematic transformations during 
mitosis, observations were made on the root apex of Allium cepa fixed and stained after Estable and Sotelo.

It would seem that the strongly staining filamentous structures visible in some anaphase chromosomes and interpreted by authors as nucleolonema, should rather be considered as fragments of the spiral chromosome structure and have nothing to do with the nucleolonema proper.

\section{Cytochemical investigations with the use of basic and acid stains}

The cytochemical studies consisted in staining the tissues with basic (e.g. toluidine blue) and acid (fast green) dyes at various $\mathrm{pH}$ values, immediately or after previous removal of nucleic acids by means of hot TCA or $5 \mathrm{~N} \mathrm{HCl}$ or after removal of certain types of proteins (with trypsin or $5 \mathrm{~N} \mathrm{HCl}$ ).

The results of this analysis prove the presence of RNA and proteins (Table III) in both structural components of the nucleolus.

The presence of RNA is indicated by the positive direct staining with toluidine blue at $\mathrm{pH} 3.4$, and the negative result after removal of nucleic acids. At pH 3.4 the substrate stains stronger that the nucleolonema. This intensive staining proves that the substrate contains a large amount of RNA in a state capable of binding the dye. The weak staining of the nucleolonema indicates either a low RNA content in the nucleolonema or the binding of RNA with proteins masking a large part of its active groups capable of reacting with the basic stain.

Evidence of the presence of free anionic and cationic groups of proteins in the nucleolus may be found both in the results of staining with toluidine blue at $\mathrm{pH} 7.4$ after RNA removal and also in the result of staining with fast green directly or after TCA hydrolysis at $\mathrm{pH} 3.4$ and 7.4.

At $\mathrm{pH}$ 7.4, after RNA removal, toluidine blue stains very strongly the nucleolonema, whereas it hardly affects the substrate. This would mean that the nucleolonema contains numerous free anionic groups binding the dye cations, whereas in the substrate they are very scarce or absent. The negative result of staining at $\mathrm{pH} 3.4$ after hydrolytic RNA removal indicates that these groups are not phosphate groups of phospholipid. Thus, the staining of the nucleolonema must have been caused by the binding of dye cations by the free carboxyl groups of the proteins. This fact indicates a large content of acidic amino acids in nucleolonematic proteins. The negative staining reaction of the substrate proves the absence of dissociable acidic groups.

Staining with fast green allows to conjecture the presence of dissociable basic groups binding the dye anions. Such groups are present in the proteins, in the basic rests of histidine, lysine and arginine. Their dissociation constants are different. The guanidine group of arginine exibits the highest $\mathrm{pH}$ value. This group is still highly dissociated at such high 
$\mathrm{pH}$ values at which dissociation of the remaining basic groups in the proteins is almost completely suppressed. The imidazole group of histidine has the lowest $\mathrm{pH}$ value. Owing to these differences, differential staining may be achieved by suitable adjustment of $\mathrm{pH}$. Alfert and Ges chwind (1953) based on this principle their method of cytochemical identification of histones.

After staining with fast green at $\mathrm{pH} 3.4$ one could observe the intensively-stained substrate and the somewhat weaker-stained nucleolonema. At this $\mathrm{pH}$ value the free basic groups of proteins are almost completely dissociated. The differences in staining intensity thus indicate directly the differences in the amount of dissociable basic groups in the substrate and in the nucleolonema, demonstrating the quantitative predominance of these groups in the substrate. The enhanced intensity of staining of the protein structures after hydrolysis in TCA proves that a part of the groups capable of binding the dye was previously bound to RNA.

At higher $\mathrm{pH}$ values the degree of dissociation of the basic groups decreases. First there occurs a suppression of dissociation in the histidine

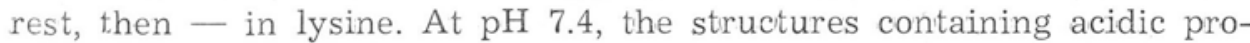
teins with a small amount of lysine and arginine stain no more with fast green. However, the basic proteins with a high content of free lysine and arginine groups will continue to bind the dye anions. In sections stained with fast green at $\mathrm{pH} 7.4$ the substrate of the nucleolus remained colourless, even when RNA was completely removed, but the nucleolonema was stained. These results points to the presence of basic proteins in the nucleolonema and indicate that in the substrate of the nucleolus, arginine and lysine groups are few or blocked.

\section{SUMMARY AND CONCLUSIONS}

The observations presented in this paper show that the nucleolus is not homogeneous, but has an internal structure. This structure was found in all the types of cells examined. It is composed of filamentous nucleolonema, readily stained with acid and basic dyes, and of an amorphous substrate with a weaker staining affinity. The nucleolonema is embedded in the substrate forming a characteristic skein.

The pattern of the nucleolonematic structure and the amount of the substrate are dependent on the physiological state of the cells. In very active cells the nucleoli are large with a well developed, loose nucleolonematic pattern and a large amount of substrate, whereas in the cells with a low physiological activity they are small, the nucleolonema is contracted and condensed, and the substrate is scarcely visible.

Fixatives have a marked effect on the structure of nucleoli accentuating or masking it. 
The homogeneous structure of the nucleoli visible after application of most fixatives is the result of coalescence of the structural components of the nucleoli, caused by those constituents of the fixative which dissolve basic proteins or RNA.

The best of the fixatives tested, revealing the nucleolonematic skein proved to be a mixture of equal parts of $1 \%$ chromic acid and $40 \%$ formalin (chrom-formalin 0.5-20) and a mixture of equal parts of $2 \%$ uranyl nitrate and $20 \%$ formalin (uranyl-formalin $1-10$ ). In these fixatives formalin is the essential agent which fixes the internal structure of the nucleolus by acting mainly on the protein, whereas chromic acid or uranyl nitrate improve the fixation of the nucleolus acting on RNA and phospholipids.

Particularly convenient for observation of the internal structure of the nucleolus are apical meristems of Allium cepa and Cucurbita pepo roots fixed in chrom-formalin $0.5-20$ and stained with Newton's crystal violet. In these preparations the peripheral part of the root, consisting of the protoderm and the external part of the cortex, exhibits a strong staining of the nuclear chromatin and chromosomes, whereas the nucleoli stain weakly, and their contents are coalesced. In the central part of the root (inner contex and central cylinder), the nuclear chromatin and chromosomes are compleitely colourless, the nucleoli, on the contrary, are intensively stained and their filamentous, nucleolonematic structure is distinctly visible. This is due to the highly specific colour reaction of the nucleolus and chromosomes conditioned by the fixative. For visualizing the homogeneous substraite in the nucleolus, Heidenhain's haematoxylin is most suitable with long-lasting differentiation in iron alum. The differentiation time is dependent on the fixalive used.

The existence of the nucleolonematic structure of the nucleolus was demonstrated by this method in all types of cells investigated from various plants. This structure corresponds to the submicroscopic differentiation of the nucleolus, and to its varying optical density in the living cell.

In my opinion there is no doubt that the filamentous skein in the nucleolus is not an artefact. It has been observed in all the tissues examined derived from various systematic groups of plants. It can be demonstrated by the use of various fixatives and staining methods. The fixing mixtures employed are good cytological fixatives which do not produce artefacts even in such sensitive components of the cell as the mitochondria. Neither should the filamentous structure occurring in the nucleolus be considered as a specific form of vacuolisation. This is demonstrated conclusively in the enormous nucleoli of the secondary nuclei of embryo sacs-where only the amorphous substrate undergoes vacuolization (table II, 6).

The cytochemical experiments carried out indicate that the nucleolar 
structures have a high protein and RNA content. Both these substances occur in the substrate as well in the nucleolonema.

The nucleolonema, which stains in'ensively with basic dyes at high $\mathrm{pH}$ after removal of nucleic acids, should contain proteins with a high amount of dicarboxylic amino acids. It is significant that these amino acids occur in a rather high concentration in ribosome proteins. B o $\mathrm{n} n$ e $\mathrm{r}$ and Varner (1965) report that the amount of glutamic and aspartic acids in ribosome proteins is 10.2 and 9.5 moles in 100 moles of protein, respectively. The intensity of staining of the nucleolonema with fast green at high $\mathrm{pH}$ proves the presence of basic proteins with free lysine and arginine cationic groups.

The strong staining reaction of the homogeneous substrate with fast green at low $\mathrm{pH}$ and its failure to stain at $\mathrm{pH} 7.4$ seem to indicate the presence of proteins with a high conitenit of histidine, the dissociation of which is reversed in alkaline medium, and a low content of free basic groups of lysine and arginine.

The above described results show a resemblance in the composition of ribosome proteins and those occurring in the nucleolonema. This similarity may be an indication either of ribosome proteins production in the nucleolonema or of their accumulation. B o n n e r and V a r n e r (1965) are of the opinion that synthesis of these proteins takes place within the nucleolus.

The second chemical component of the nucleolus is RNA. Its presence has been demonstrated in the present study both in the nucleolonema and in the substrate. The differences in the intensity of the staining reaction with basic stains in acid medium point to differences in the content of free phosphate groups capable of binding the dye. The relatively weak staining of the nucleolonema may either be evidence of a low RNA content or of the binding of a large part of the phosphate groups of RNA with basic protein groups. The intensive staining of the substrate is a direct proof of a high RNA concentration.

There is no doubt (Birnstie 1 1967) that ribosome RNA synthesis takes place in the nucleolus. It seems therefore, that these staining reactions point to sites of formation and of accumulation of RNA.

Confrontation of the results of the present study with contemporary views on the submicroscopic structure of the nucleolus (M arinoz zi 1964, P erry 1966, Biernstie 1 1967) suggests - contrary to the widespread opinion, but in accordance with the latest results of $\mathrm{L}$ a $\mathrm{Cour}$ (1966) - that the filamentous nucleolonema corresponds to the fibrillar zone, whereas the amorphous substrate - to the granular zone of the nucicolus.

Observations concerning the transformations of nucleolar structure during mitosis demonstrated that during prophase the nucleolonematic skein aggregates and becomes more compact, and the homogeneous sub- 
strate gradually disappears. These changes result in a diminution of the volume of the nucleoli up to their sudden dissolution in late prophase. A symptom of disappearance of the substrate is a change in the shape of the nucleolus which becomes irregular. The successive steps in reconstruction of the internal structure in the nucleolus in telophase are so to say a reversion of those occurring in prophase. The nucleolonema which appears as the first element in the nucleolus, is initially very compact. The increase in volume of the nucleoli observed towards the end of telophase is due to the reconstruction of the homogeneous substrate and to the growth and loosening of the nucleolonema. A similar interpretation of the cyclic changes in the nucleolus in the course of mitosis has been given by Stevens (1965).

The results of observations on living cells require separate interpretation. The plant material accessible for studies in vivo is not convenient for observations of the internal nucleolar structure. It consists mainly of little active, highly specialized cells in which the nucleoli are minute and exhibit a compact structure. Nevertheless, in the nucleoli of living plant cells, zones of differential optical density are frequently observed. The structure of the nucleoli in living staminal hair cells of Tradescantia shows a certain similarity to the nucleolonematic skein observed in the fixed material. It seems, therefore, that the nucleolonematic structure of the nucleolus revealed after appropriate fixation and staining is not an artefact but has its counterpart in the living cell.

The investigations were performed in the Botanical Institute, Warsaw University. The authoress wishes to thank professor $\mathrm{H}$. T e le ży ńsk 1 for his guidance and valuable advice in the course of the work as well as for his critical reading of the paper.

\section{REFERENCES}

Albaneze M. P., Boloquari A., Maria de Simone, 1963, Orientamenti sulle secondo fase di albiolita dei nucleclo, Caryologie, 16: 57-66.

A 1 fert M., Geschwind I. I., 1953, A selective staining method for the basic proteins of cell nuclei, Procl. Natl. Ac. Sci. USA, 39: 991-999.

B ern hard W., H a g e n a $\mathrm{F}$., O berling Ch., 1955, l'ultrastructure du nucléole de cellules normales et cancérénses, Exptl. Cell. Res., 9: 88-100.

Birnstiel M., 1967, The nucleolus in cell metabolism, Ann. Rev. Plant Physiol., 18: $25-58$.

B on ner J., V a rner J. E., 1965, Plant biochemistry, Academic Press, New York, London.

Bourne G., Danielli J., 1960, Nucleolus, Intern. Rev. Cytol., 10: 142-143.

Chouinard L. A., 1965, Evidence for the existence of two types of nucleolar ribonucleoprotein in root meristematic cells of Vicia faba, Canadian J. Bot., 44: 1403-1411.

Davis J. M. G., 1960, The ultrastructure of the mammalian nucleolus, The Cell 
Nucleus: $3-15$, Proc. Inf. Depart. Radiotherapeutics University of Cambridge 1959, London, Toronto, 1960.

Estable C., S ot el o J. R., 1951, Una nueva estruxtura celular: el nucleolonema, Inst. Inv. Cien. Biol., 1: 105-126.

Estable C., Sotelo J. R., 1955, The behaviour of the nucleolonema during mitosis, Fine structure of cells: 170-190, P. Noordhoff Ltd.

Estable C. et all., 1966, Raport of the nucleolus nomenclature commitee, Nat. Cave Inst. Mon., 23: 573-574.

Hertl M., 1957, Zum Nukleolusproblem, Zeitschr. für Zellforsch., 46: 18-51.

L a C our L. F., 1966, The internal structure of nucleoli, C. D. Darlington and K. R. Levis: Chromosomes today, 1: 150, London, Oliver and Boyd.

Lafontaine J. G., 1958a, A particulate component found in nucleoli of Allium cepa and Vicia faba, J. Biophys. and Bioch. Cytol., 4: 229-230.

Lafontaine J. G., 1958b, Structure and mode of formation of the nucleolus in meristematic cells of Vicia faba and Allium cepa, J. Biophys. and Bioch. Cytol., 4: $777-784$.

Marinozzi V., 1964, Cytochimie ultrastructurale des nucléole-RNA et protéines intranucléolaires, J. Ultrastruct. Res., 10: 433-456.

Perry R. P., 1966, Science, 153 (3732) 8: 214-219.

Rodkiewicz B., 1959, The nucleolus structure in some plant cells, Exptl. Cell. Res., 18: 407-410.

Serra J. A., 1958, Interpretation of nucleolar inclusion, Nature, 181: 1544-1545.

S e t t e r field G., 1961, Structure on composition of plant cell organelles in relation to growth and development, Canadian J. of Botany, 39.

S i t t e P., 1959, Die Ultrastruktur der Wurzelmeristemzellen der Erbse (Pisum sativum L.), Protoplasma, 49.

Sit te P., 1965, Bau und Feinbau der Pflanzenzelle, Gustav Fischer Verlag, Jena.

Stevens B., 1965, The fine structure of the nucleolus during mitosis in the grasshopper neuroblast cell, J. Cell. Biol., 24: 349-369.

Yasuzumi G., S a wa d a J., 1958, Electron microscope researches on the ultrastructure of nucleoli in animal tissues, Z. Zellforsch., 48: 10-23.

Z enkteler IV., 1959, Spostrzeżenia nad budową jąderek, Acta Soc. Bot. Pol., 28: $477-487$.

\section{Struktura jaderek $u$ okrytonasiennych}

\section{Streszczenie}

Badania w mikroskopie elektronowym wykazały heterogenność jąderek, zarówno w tkankach roślinnych, jak i zwierzęcych. Interpretacja złożonej struktury jąderka jest jednak nadal przedmiotem licznych prac prowadzonych na różnym materiale w oparciu o różne metody cytologiczne i cytochemiczne. Zdaniem niektórych autorów na wewnętrzną strukturę jąderka składają się dwa elementy: nitkowata nukleolonema i niezróżnicowane podłoże, w którym jest ona pogrążona; inni nie widzą podstaw do wyróżniania tych struktur.

Celem mojej pracy była próba wyjaśnienia tych rozbieżności i bliższe zbadanie struktury jąderka w mikroskopie świetlnym. Realizowałam to przez: 1. obserwacje witalne; 2. zbadanie wpływu różnych utrwalaczy i opracowanie metody utrwalania wewnętrznej struktury jąderka; 3 . ustalenie, jakie czynniki wplywają na zróżnicowanie morfologiczne struktury jąderka, biorąc pod uwagę: a) zróżnicowanie komór- 
ki i jej stan fizjologiczny, b) typ budowy jądra, c) przemiany zachodzące w mitozie; 4. badania cytochemiczne.

Orientacyjne badania przeprowadziłam na kilkunastu gatunkach należących do różnych grup systematycznych w obrębie okrytonasiennych. Szczegółowe obserwacje witalne przy zastosowaniu kontrastu fazowego i anoptralnego przeprowadziłam na skórce z łusek Allium cepa, na włoskach z liści Cucurbita pepo oraz na włoskach pręcikowych Tradescantia virginiana we wczesnych stadiach rozwojowych. Podstawowymi obiektami badań na materiale utrwalonym były wierzchołki korzeni Allium cepa, Vicia faba i Cucurbita pepo oraz woreczki zalążkowe Delphinium sp. i Aconitum napellus. Do utrwalania użyto kilkudziesięciu różnych utrwalaczy (różne modyfikacje chrom-aceto-formaliny, chrom-formaliny, aceto-formaliny, dwuchrom-formaliny, lantano-formaliny i uranylo-formaliny). Podstawowymi metodami barwienia były: hematoksylina żelazista i fiolet gencjanowy.

Badania cytochemiczne przeprowadzono przy zastosowaniu barwników kwaśnych (zieleń trwała) i zasadowych (błękit toluidyny i fiolet krezylu) w zbuforowanych roztworach o różnym pH. Kwasy nukleinowe usuwano hydrolizując preparaty w roztworach kwasu solnego i kwasu trójchlorooctowego. Do usunięcia białek stosowano trypsynę.

Spodziewano się, że podstawowe znaczenie dla interpretacji badań przeprowadzonych na materiale utrwalonym będą miały wyniki obserwacji na żywych komórkach. Obiekty roślinne nie są jednak dogodnym materiałem do obserwacji witalnych jąderka. Łatwo dostępny materiał stanowią zazwyczaj komórki zróżnicowane, o małej intensywności podstawowych syntez, mające drobne jąderka. Do takich należą np. badane przeze mnie komórki skórki z luski Allium cepa. Również pozostałe obiekty moich obserwacji, a mianowicie różne typy włosków łodygowych i liściowych oraz merystematyczne komórki we wczesnych stadiach rozwoju włosków pręcikowych Tradescantia wyróżniają się drobnymi rozmiarami jąderek. Mimo to stwierdziłam, że jąderka mają in vivo, niezależnie od występującej czasem wakuolizacji, pewną niejednorodność struktury. Widać w nich ciemniejsze pasma o nieostrych granicach (tabl. I, 1-3).

Dotychczasowe obserwacje tkanek utrwalonych złożonymi utrwalaczami powszechnie stosowanymi w praktyce cytologicznej, jak np. utrwalacz Navashina, nie ujawniały $w$ jąderku wewnętrznej struktury. W pierwszej serii moich doświadczeń nad mechanizmem utrwalania struktury w jąderku zastosowałam modyfikację utrwalacza Navashina o zmniejszającej się ilości kwasu octowego. Była to chrom-aceto-formalina (CrAF) o następującym składzie procentowym: 0,5 - 4-20;0,5 - $1-$ $20 ; 0,5-0,5-20 ; 0,5---20$.

Analiza tej grupy utrwalaczy wykazała, że chrom-aceto-formalina w proporcjach powszechnie stosowanych (CrAF $0,5-4-20$ ) daje jednolitą strukturę jąderka. Homogenizacja ta wiąże się z rozpuszczającym działaniem kwasu octowego na histony i zasadowe białka, których utrwalenie powoduje formalina. Złożoną strukturę jąderka ujawnić jednak można, zmniejszając zawartość kwasu octowego w utrwalaczu. Składają się na nią dwa elementy: nitkowata nukleolonema i niezróżnicowane podłoże, w którym jest ona pogrążona.

Analiza preparatów $\mathrm{z}$ merystemów wierzchołkowych korzeni utrwalonych w CrAF $0,5-0,5-20$ i CrAF $0,5-1-20$ wykazała obecność na tym samym preparacie różnych obrazów wewnętrznej struktury w jąderku - od układu luźnego w partiach wewnętrznych korzenia do silnie zlepionych w części zewnętrznej. Obszar tego zróżnicowania zależny jest od składu utrwalacza. Fakt ten ma decydujące znaczenie dla interpretacji obserwowanych struktur. Obrazy mniej lub bardziej zlepionej struktury na tym samym preparacie powstałe w wyniku działania utrwalacza dowodzą, że nie można interpretować tych struktur jako artefaktów; artefaktem jest jednolita struktura jąderka. 
W oparciu o doświadczenia przeprowadzone na tkankach utrwalonych chrom-formaliną, aceto-formaliną, uranylo-formaliną, dwuchrom-formaliną i lantano-formaliną wykazano, że podstawowym składnikiem utrwalającym wewnętrzną strukturę jąderka jest formalina. Korzystny jest przy tym niewielki dodatek kwasu chromowego (chrom-formalina $0,5-20$ lub $0,2-10$ ) lub azotanu uranylu (uranylo-formalina 1 - 10) utrwalających kwasy nukleinowe.

Porównanie tkanek różnych pod względem funkcjonalnym pozwoliło mi stwierdzić, że podstawowa, dwoista organizacja jąderka jest taka sama w tkankach o różnych funkcjach i różnej aktywności fizjologicznej. Stwierdzono natomiast duże różnice w rozmiarach jąderka oraz w ukształtowaniu i ilości nukleolonemy oraz homogennego podłoża (tabl. I, 4-6; II, 1-7). Duża aktywność podstawowych syntez determinuje luźny układ nukleolonemy i znaczną ilość podłoża, a struktura zbita, z przewagą ilościową nukleolonemy charakteryzuje komórki o niskim metabolizmie. Stanowisko systematyczne rośliny, a także różnice kariologiczne wyrażające się w retikularnej lub euchromocentrycznej strukturze jądra, nie mają wpływu na ukształtowanie wewnętrznej budowy jąderka (tabl. I, 4-6).

Badania cytochemiczne przy zastosowaniu barwników zasadowych przy pH 3,4 wykazały obecność RNA w znacznej koncentracji w podłożu i nieco mniejszej w elemencie nitkowatym.

Białka nukleolonemy charakteryzuje obecność reszt zasadowych aminokwasów lizyny i argininy wiążących zieleń trwałą przy pH 8,9 przy jednoczesnym występowaniu znacznych ilości reszt dwukarboksylowych aminokwasów, na co wskazuje intensywne zabarwienie błękitem toluidyny i fioletem krezylu przy pH 7,4 po całkowitym usunięciu kwasów nukleinowych przez TCA.

Białka niezróżnicowanego podłoża jąderka mają zupełnie inny charakter. Analiza zabarwienia zielenią trwałą przy różnym pH wskazuje jedynie na obecność reszt histydyny, nie wykazuje natomiast reszt silniej zasadowych aminokwasów. Barwniki zasadowe nie wybarwiają podłoża po usunięciu kwasów nukleinowych nawet przy wysokim pH. Białka podłoża jąderka nie zawierają zatem wolnych grup karboksylowych.

Wyniki tych doświadczeń wyjaśniają, dlaczego po niektórych utrwalaczach jąderka wykazują strukturę jednorodną. Zlepiający wpływ kwasu octowego na strukturę jąderka polega na upłynnieniu białek zasadowych w nukleolonemie. Zlepienie struktur jąderka może być wywołane również upłynnieniem RNA; tak działa dwuchromian potasu.

Na podstawie przeprowadzonych przeze mnie badań sądzę, że dwoista struktura jąderka, złożona z nukleolonemy i niezróżnicowanego podłoża, jest charakterystyczna dla wszelkich typów roślin okrytonasiennych, a ujawnienie jej w mikroskopie świetlnym zależy od sposobu utrwalenia.

\section{Instytut Botaniki}

Uniwersytetu Warszawskiego 